\title{
Salinity levels in growth and production of curly lettuce (Elba, Cristina and Veneranda) grown in hydroponic system
}

\author{
Josilda de França Xavier ${ }^{1} *$, Carlos Alberto Vieira de Azevedo ${ }^{1,2}$, Julio Cesar Rodrigues de Sales ${ }^{1}$, Marcia \\ Rejane de Queiroz Almeida Azevedo ${ }^{3}$, Josely Dantas Fernandes ${ }^{3}$, Vera Lúcia Antunes de Lima ${ }^{1}$, Josivanda \\ Palmeira Gomes ${ }^{1}$, Antônio Fernandes Monteiro Filho ${ }^{3}$
}

\author{
${ }^{1}$ Federal University of Campina Grande, Academic Unit of Agricultural Engineering, Campina Grande, 58429-140, \\ Paraíba, Brazil \\ ${ }^{2}$ Productivity CNPq Fellowof Reseach, 1B level, Brazil \\ ${ }^{3}$ State University of Paraíba, Center of Environmental and Agrarian Sciences, Lagoa Seca, 58117-000, Paraíba, Brazil
}

\section{*Corresponding author: josildaxavier@yahoo.com.br}

\begin{abstract}
The objective of this research was to evaluate the different salinity levels on growth and production of three cultivars (Elba, Cristina and Veneranda) of curly lettuce in a hydroponic system using the Nutrient film technique (NFT). The design was randomized blocks in a split plot scheme, in which treatments constituted of nutrition solutions: $\mathrm{S}_{1}=$ Furlani $\left(1.9 \mathrm{dS} \mathrm{m}^{-1}\right)$ and six solutions prepared from Furlani solution in order to present the electrical conductivities of $\left(\mathrm{S}_{2}=2.4 ; \mathrm{S}_{3}=2.9 ; \mathrm{S}_{4}=3.4 ; \mathrm{S}_{5}=3.9 ; \mathrm{S}_{6}=4.4\right.$ and $\mathrm{S}_{7}=4.9 \mathrm{dS}$ $\mathrm{m}^{-1}$ ) with three repetitions. The electrical conductivities were obtained by addition of $\mathrm{NaCl}$. The subplots corresponded to the cultivars Elba, Cristina and Veneranda. The following variables were evaluated: Number of leaves per plant (NLP); Total production (TP); Commercial production (CP); Stem diameter (SD); Fresh leaf mass (FLM), Dry leaf mass (DLM) and Dry stem mass (DSM). Nutritional solutions $\left(S_{1}\right.$ and $\left.S_{2}\right)$ promoted the best results for all variables studied. The highest number of sheets (NS) were found in cultivars Elba and Veneranda when the solutions were used $\left(S_{1}\right.$ and $\left.S_{2}\right)$. The highest yields for (TP) (PC) and (FLM) were found in the cultivar Veneranda with nutrient solutions $\left(S_{1}\right.$ and $S_{2}$ ). The highest value for dry leaf mass (DLM) and dry stem mass (DSM) was found in the cultivar Veneranda.
\end{abstract}

Keywords: Electrical conductivity; hydroponics; Lactuca sativa L; nutritional solutions; productivity.

Abbreviations: NFT_Nutrient Film Technique; $\mathrm{S}_{1}$ Furlani solution; FAO_Agriculture Organization; WHO_World Health Organization; CAES_Center for Agricultural and Environmental Sciences; SUP_State University of Paraíba; Hp_Hydrogenionic potential; EC_Electrical Conductivity; TDS_Total Dissolved Solids; LIS_Laboratory of Irrigation and Salinity; days after transplantation_DAT; SC_Sodium chloride; SH_Sodium Hydroxide; HA_Hydrochloric acid; $\mathrm{dS} \mathrm{m}^{-1}$ _deciSiemens por metro; Hi_hydronium ions; Log_Logarithm; EVA_Ethylene Vinyl Acetate; UAEA_Academic Unit of Agricultural Engineering; UFCG_Federal University of Campina Grande; Kg_kilogram; Cm_Centimeter; CV_coefficient of variance; DF_degree of freedom; ns_not significant; APHA_American Public Health Association; NS_Number of sheets; SD_Stem diameter; TP_Total Production; CP_Commercial production; FSM _ Fresh Stem Mass; FLM_Fresh Leaf Mass; C_Degree ${ }^{\circ} \mathrm{C}$; ha_hectare; N_nitrogen; P_phosphor; K_potassium; mm_millimeter; g_gramme; $\mathrm{mol} / \mathrm{L}^{-1} \_$Molarity; SISVAR_statistical analysis system; ETV_Evapotranspiration Volume; Vi_Volume of solution consumed in the time interval de $24 \mathrm{~h} ; \Delta \mathrm{T}_{-}$Time interval between readings; $n \_n u m b e r$ of plants in the profile in the time interval, $\Delta T$; $L_{-}$liter; $H_{-} h o u r$.

\section{Introduction}

Agriculture is responsible for about $70 \%$ of global water consumption (WHO, 2013). However, in many situations the water is indirectly reused in evapotranspiration process in plants and then incorporated into the water vapor of the atmosphere, not being directly reused.

The quality of the irrigation water is decisive not only in terms of its physical, chemical and biological characteristics, but also of the suitability for the specific use intended (Ayers and Westcot, 1999).

In the last years, several studies have demonstrated the potential of using saline water in the production of vegetables in hydroponic cultivation (Dias et al., 2011; Santos et al., 2012; Silva et al., 2011). However, to obtain success in the production of vegetables using these waters, it is necessary to adapt irrigation management and choose tolerant crops. Studies on the use of brackish waters in hydroponic systems have dealt with different strategies for the use of these waters associated or not with a fresh water source. Soares et al. (2010) studied the use of fresh and brackish waters, alternating them in the preparation of the nutrient solution or in the replacement of evapotranspiration in a hydroponic system, while their experiments were carried out in different periods.

The use of hydroponics has emerged as an alternative to problems such as the low availability of soils suitable for agriculture, incidence of certain soil diseases that are 
difficult to control by chemical, sanitary or genetic, increasing the efficiency of water use and the desire to increase production and improve food quality. (Souza Neta et al., 2013).

The nutritive solution for hydroponic cultivation is of fundamental importance, as the growth and development of the crop will depend on an adequate formulation (Oliveira et al., 2014).

The quality of the water used in the preparation of the nutrient solution is a fundamental factor to obtain high productivity and product quality, whether in NFT system (Gondim et al., 2010; Paulus et al., 2010) or cultivation in substrate (Dias et al., 2011; Santos et al., 2012; Silva et al., 2011).

Oscillations in electrical conductivity (EC) are related to the consumption of water and nutrients by plants and the evaporation of nutrient solutions that is occurred (Monteiro Filho et al., 2017). Silva et al. (2015) studied two levels of nutrient solution availability ( 2.75 and $5.50 \mathrm{~L}$ per pack of 24 plants) and four levels of water electrical conductivity (EC): 0.43 (control); $3.09 ; 6.87$ and $8.53 \mathrm{dS} \mathrm{m}^{-1}$.

Lettuce (Lactuca sativa L.) is a herbaceous plant, originating from a temperate climate, belonging to the Asteracea family and the subfamily Cichoriaceae, certainly one of the most popular vegetables that consumed both in the world and in Brazil. Virtually all lettuce cultivars thrive in mild climates, especially during the growing season. The occurrence of higher temperatures accelerates the cultural cycle, which may result in smaller plants depending on the genotype, because the budding occurs earlier (Henz and Suinaga, 2009). Lettuce stands out in the national scenario of hydroponic crops, whereas approximately $80 \%$ of the Brazilian lettuce production comes from this system (Alves et al., 2011). According to Silva and Schwonka (2001), although the cost of implementing a hydroponic system is high but in the short term it is possible to recover the invested capital. The economic analysis of hydroponic lettuce production by the same authors was concluded that in 2.5 years the investment cost of $R \$ 56.343 .00$ can be recovered. This is possibly due to the good profitability of the system. The objective of this research was to evaluate the different levels of salinity in the growth and production of three cultivars (Elba, Cristina and Veneranda) of curly lettuce in a hydroponic system using the Laminar Flow of Nutrients Flow Technique (NFT).

\section{Results and discussion}

\section{pH and electrical conductivity (EC) and water consumption} of nutrient solutions

During the development of the crop, changes in $\mathrm{pH}$ were observed due to consumption of nutrient solution by the plants (Figure 1A), while variation was from 5.0 to 7.8 during the experiment. The $\mathrm{pH}$ values were higher than recommended. According to Castellane and Araújo (1995), the $\mathrm{pH}$ ranged 6.0-6.5, which is best for plant development. Furthermore, the $\mathrm{pH}$ provides an indirect effect on the solubility of nutrients, whereas in high values precipitates some elements such as: calcium, phosphorus, iron and manganese, which are no longer available to plants (Gomes et al., 2011).

The acidity or alkalinity of solutions is indicated by measuring the concentration of hydrogen ions $\left(\mathrm{H}^{+}\right)$, being represented by the $\mathrm{pH}$ scale. Solutions with $\mathrm{pH}$ equal to 7.0 are considered neutral, while values below or above neutrality characterize acidity and alkalinity, respectively. According to Martinez, (2002), the appropriate range of this parameter for lettuce culture varies between 5.5 and 6.5 in hydroponic systems.

This result may be associated with an imbalance in the absorption of cations and anions, known as anionic absorptions, such as nitrate ion $\left(\mathrm{NO}_{3}{ }^{-}\right)$. They provide an increase in the $\mathrm{pH}$ of the solution through the release of bicarbonates $\left(\mathrm{HCO}_{3}{ }^{-}\right)$or hydroxyls $\left(\mathrm{OH}^{-}\right)$by the roots, while the opposite occurs if cations, such as ammonium ions $\left(\mathrm{NH}_{4}{ }^{+}\right)$are absorbed more quickly than anions, with the release of hydrogen ions $\left(\mathrm{H}^{+}\right)$(Braccini et al., 1999).

For the development of the experiment, different levels of salinity were determined from the Furlani solution $S_{1}=100 \%$ of the Furlani solution and the others added sodium chloride $(\mathrm{NaCl})$ in order to present the following electrical conductivities: $\left(\mathrm{S}_{2}=2.4 ; \mathrm{S}_{3}=2.9 ; \mathrm{S}_{4}=3.4 ; \mathrm{S}_{5}=3.9 ; \mathrm{S}_{6}=4.4\right.$ and $\mathrm{S}_{7}=4.9 \mathrm{dS} \mathrm{m}^{-1}$ ). In this work, the EC levels of all solutions were maintained taking into account $20 \%$ more or less than the initial EC. Oscillations in electrical conductivity $(E C)$ are related to the consumption of water and nutrients by plants and the evaporation of nutrient solutions that is occurred during the conduct of the experiment (Fig. 1B).

We observed that the greatest decreases in the value of electrical conductivity were observed 12 th day after transplantation, which occurred in an interval of $24 \mathrm{~h}$ whose values of $(E C)$ were $S_{2}=1.78 ; S_{3}=2.56 ; S_{4}=2.38 ; S_{5}=2.58 ; S_{6}$ $=3.31$ and $S_{7}=4.26 \mathrm{dS} \mathrm{m}^{-1}$, respectively. The highest values of (EC) observed in the solutions were $S_{2}=3.27 ; S_{3} 4.94 ; S_{4}=$ $6.66 ; S_{5}=6.0 ; S_{6}=6.42$ and $S_{7}=7.41 \mathrm{dS} \mathrm{m}^{-1}$, respectively. These values were observed 170th day after transplantation. The latter condition may be associated with the temperature recorded inside the protected environment. At high temperatures, the plants absorb more water than nutrients due to the high rate of transpiration. As a final result, there is a more concentrated solution; therefore, a larger $(E C)$, the same type of behavior being reported in previous work in hydroponics (Soares et al., 2010; Alves et al., 2011; Lira et al., 2015; Soares et al., 2015).

Some authors disagree with ideal EC range to be used in hydroponic lettuce cultivation, which may vary depending on the cultivar and climatic conditions (Helbel Júnior et al., 2007).

Figure $1 C$ shows that in the first days after transplanting (DAT), there were no major variations in water consumption by the plants in modified nutrient solutions. However, as of 7 th DAT, there was a significant increase in water consumption, characterizing well the difference between the tested solutions whose highest averages were recorded in the last days of the evaluation.

It can be observed that the consumption of nutrient solutions by the curly lettuce plants was increased from the 15 th day on for all the solutions, with emphasis on the nutrient solution $\mathrm{S} 4=3.4 \mathrm{dS} \mathrm{m} \mathrm{m}^{-1}$, which stood out from others with average consumption on the 16th and 17 th days after transplanting (DAT) of 9.0 and $8.1 \mathrm{~L} \mathrm{plant}^{-1}$ day $^{-1}$, respectively (Fig. 1 C), while the nutrient solution $\mathrm{S}_{3}=2.9 \mathrm{dS}$ $\mathrm{m}^{-1}$ showed a decreased average consumption of $4.0 \mathrm{~L}$ plant $^{-1}$ day $^{-1}$. Variations in consumption due to different cultivars of curly lettuce are also reported in the literature; Sanchez (2007) and Monteiro Filho et al. (2018).

Table 1 shows that in lettuce, there was a significant effect $(p<0.01)$ for the nutrient solution $(S)$ on variables number of leaves per plant (NLP), Total production (TP) and Fresh stem 
mass (WSF). For the variables of Commercial production (CP) and Fresh leaf mass (FLM), there was no significant effect on stem diameter (SD) ( $p \leq 0.01$ and 0.05$)$.

Number of leaves per plant (NLP), Stem Diameter (SD), Total Production (TP), Commercial Production (CP), Fresh Leaf Mass (FLM), Dry Leaf Mass (DLM) and Dry Stem Mass (DSM)

Table 1 shows a significant $(\mathrm{p}<0.01)$ for the nutrient solution factor (S) on variables Leaf number per plant (NLP), Total production (TP) and Fresh stem mass (FSM). For the variables of Commercial production (CP) and Fresh leaf mass (FLM), there was no significant effect for stem diameter (SD) $(0.01 \leq \mathrm{p}<0.05)$.

Table 1 shows that the cultivar factor (C), has a significant effect on Leaf Number per Plant (NLP), Commercial Production (CP) and Fresh leaf mass (FLM), Dry Leaf Mass (DLM) and Dry Stem Mass (DSM) at the level of $1 \%$ probability $(p<0.01)$, whereas for the Total Production variable (TP) the significance level of $5 \%$ probability $(0.01 \leq p$ $<0.05$ ) was observed. The variable, stem diameter (SD) did show any significant effect. The interaction between factors can be seen in Table 1, that there was no significant effect for any variable analyzed.

\section{Number of leaves per plant (NLP)}

The isolated effect of the solutions on the Number of leaves per plant (NLP), appeared that the solutions $\left(\mathrm{S}_{1}=1.9 ; \mathrm{S}_{2}=\right.$ 2.4 and $\mathrm{S}_{3}=2.9 \mathrm{~S} \mathrm{dm}^{-1}$ ) stood out from others with averages of 17.09; 16.61 and 16.14, respectively (Fig. 2A). Still in Figure $2 \mathrm{~A}$, we observed that the lower performance of the Number of leaves per plant (NLP) occurred at nutrient solution $\left(\mathrm{S}_{7}=4.9 \mathrm{dS} \mathrm{m}^{-1}\right)$. The other values were statistically similar. These results corroborate with Xavier et al. (2019), who also worked with saline water and with different cultivars of curly lettuce in a hydroponic system. However, Oliveira et al, (2011), found a significant reduction in the number of lettuce leaves under increased salinity, but differ from the results found in this work. In (Fig. 2B) it is observed that the highest values for the Number of leaves per plant (NLP) were obtained from cultivars Elba and Veneranda with averages of 15.73 and 17.40 , respectively. The cultivar Cristina had the lowest number of leaves per plant (NLP) with a value of 13.88. As verified by Cazuza Neto et al. (2014), we used saline water for preparation of the nutrient solution. The increase in saline water levels led to a decreased production of hydroponic coriander. Plants irrigated with $7.73 \mathrm{dS} \mathrm{m}^{-1}$ water showed symptoms of burning of the edges in the older leaves.

Magalhães et al. (2010), evaluated the performance of lettuce cultivars in hydroponic cultivation under two levels of electrical conductivity and observed more leaf number (27) compared to this work, which was less than the average of leaves/plant. The decrease in the number of leaves in this work can be justified by the high temperatures recorded in the cultivation environment during the entire conduct of the experiment and by the levels of electrical conductivity above that recommended for lettuce culture. Although the number of leaves is a characteristic of lettuce, high temperatures can stimulate the early flowering of the plant. Filgueira (2008) stated that the ideal temperature for growing lettuce is between 15 and $25^{\circ} \mathrm{C}$

\section{Total production (TP) and Commercial production (CP) $(g)$}

It can be seen in (Fig. 2A) that the isolated effect of the nutrient solutions used in this research showed better results for Total production (TP) when the solutions were used $\left(S_{1}=1.9\right.$ and $\left.S_{2}=2.4 \mathrm{dS} \mathrm{m}^{-1}\right)$ with averages of 217.00 and $207 \mathrm{~g}$, respectively. In Figure 2A, we observed that the lowest performance of the Total Production (TP) was in the nutrient solution $\left(\mathrm{S}_{7}=4.9 \mathrm{dS} \mathrm{m}^{-1}\right)$ average $160.46 \mathrm{~g}$.

It can be seen in (Fig. 2B) that the highest value for total production (TP) was obtained for cultivating Veneranda with average of $208.06 \mathrm{~g}$. The cultivar Cristina showed the lowest (TP) with an average of $169.18 \mathrm{~g}$. The results obtained in this research for (TP) were superior to those obtained by Xavier et al. (2019). These authors worked with lettuce cultivars in conditions similar to this research using solutions with optimized domestic wastewater and optimized saline water obtained averages for (TP) of 151.5 and $141 \mathrm{~g} / \mathrm{plant}$, respectively. Comparison of results obtained in this research with others, we observed that the values for (PT) were higher than those obtained by Monteiro Filho et al. (2014), where they worked with the replacement of up to $16 \%$ of the mineral nutrient solution by biofertiliante. They observed that the lettuce production was $2.4 \mathrm{~g} /$ plant with the use of the mineral solution. The best result for Commercial Production (CP) after applying nutrient solutions $\left(\mathrm{S}_{1}=1.9\right.$ and $\left.\mathrm{S}_{2}=2.4 \mathrm{dS} \mathrm{m}^{-1}\right)$, with averages of 174.85 and $167.11 \mathrm{~g}$, respectively (Figure 4A). The lowest performance of Commercial Production (CP) was observed in the nutrient solution $\left(\mathrm{S}_{7}=4.9 \mathrm{dS} \mathrm{m}^{-1}\right)$ with average of $128.39 \mathrm{~g}$ (Figure $4 \mathrm{~A})$. the highest value for commercial production (CP) was obtained for the cultivar Veneranda with average $171.00 \mathrm{~g}$ (Figure 4B). The cultivars Elba and Cristina did not differ significantly with averages of 143.61 and $140.25 \mathrm{~g}$.

\section{Fresh Leaf Mass (FLM), Dry Leaf Mass (DLM) and Dry Stem Mass (DSM)}

The isolated effect of the nutritional solutions was linear response (Fig. 5A). The best result was observed when the $\left(\mathrm{S}_{1}=1.9 \mathrm{dS} \mathrm{m}^{-1}\right)$ solution was used with average of 174.85 for Fresh Leaf Mass (FLM). We observed that the lowest performance of the fresh leaf mass was occurred under nutrient solution $\left(S_{7}=4.9 \mathrm{dS} \mathrm{m}^{-1}\right)$ with average of $128.39 \mathrm{~g}$ (Figure $5 \mathrm{~A}$ ). These results are greater than those obtained by Xavier et al. (2019), when they found results for the production of fresh leaf mass (FLM) for the cultivar Thaís using the optimized domestic wastewater and optimized saline well water solutions, while the averages were 129.54 and $116.20 \mathrm{~g}$. It can be seen in (Fig. 5B) that the highest value for fresh leaf mass was obtained for the cultivar Veneranda with average $171.00 \mathrm{~g}$. The cultivars Elba and Cristina did not differ between the averages, with the following averages of 143.61 and $140.25 \mathrm{~g}$. The highest value for dry mass of the leaf was obtained for the cultivar Veneranda with average of $3.17 \mathrm{~g}$ (Fig. 6A). We verified that the highest value for the dry mass of the stem (DSM) in cultivar Veneranda with average 1.11g (Fig. 6B).

\section{Materials and methods}

\section{Experimental area location}

The experiment was conducted at the Center for Agricultural and Environmental Sciences-CCAA of the State University 
Table 1. Analysis of variance, Number of leaves per Plant (NLP), Stem Diameter (SD), Total Production (TP), Commercial Production (PC), Fresh Leaf Mass (FLM), Dry Leaf Mass (DLM) and Dry stem mass (DSM) at the end of the hydroponic cultivation experiment of the three lettuce cultivars submitted to different treatments.

\begin{tabular}{|c|c|c|c|c|c|c|c|c|}
\hline \multirow[t]{2}{*}{ Source of Variation } & \multirow[t]{2}{*}{$\mathrm{DF}$} & \multicolumn{7}{|c|}{ Mean square (MS) } \\
\hline & & NLP & SD & TP & $\mathrm{CP}$ & FLM & $\mathrm{DLM}^{1}$ & $\mathrm{DSM}^{2}$ \\
\hline Solution (S) & 6 & $18.22^{* *}$ & $14.50^{\mathrm{ns}}$ & $4756.31^{* *}$ & $3062.74^{*}$ & $3062.74^{*}$ & $0.46^{\text {ns }}$ & $0.093^{\text {ns }}$ \\
\hline Block & 2 & $13.98^{\mathrm{ns}}$ & $3.36^{\mathrm{ns}}$ & $4323.21^{* *}$ & $3056.19^{*}$ & $3056.19^{*}$ & $1.85^{\text {ns }}$ & $0.30^{* *}$ \\
\hline Residue (a) & 11 & 3.64 & 7.05 & 577.17 & 651.35 & 651.35 & 0.52 & 0.03 \\
\hline Cultivar (C) & 2 & $65.25^{* *}$ & $17.64^{\mathrm{ns}}$ & $7935.77^{*}$ & $5972.07^{* *}$ & $5972.07^{* *}$ & $7.12^{* *}$ & $0.58^{* *}$ \\
\hline Cultivar x Solution & 12 & $14.08^{\mathrm{ns}}$ & $3.96^{\mathrm{ns}}$ & $1002.00^{\text {ns }}$ & $957.18^{\text {ns }}$ & $957.18^{\text {ns }}$ & $0.47^{\text {ns }}$ & $0.02^{\mathrm{ns}}$ \\
\hline Residue (b) & 92 & 9.46 & 7.82 & 1738.06 & 1016.62 & 1016.62 & 0.35 & 0.025 \\
\hline CV (a) \% & & 12.18 & 13.74 & 12.73 & 16.83 & 16.83 & 26.29 & 18.38 \\
\hline $\mathrm{CV}(\mathrm{b}) \%$ & & 19.62 & 14.47 & 22.09 & 21.03 & 21.03 & 21.61 & 15.95 \\
\hline Overall erage & & 15.67 & 19.33 & 188.73 & 151.62 & 151.62 & 2.73 & 1.00 \\
\hline
\end{tabular}

${ }^{1 \text { and } 2}$ Data transformed into $\mathrm{Vx}$ and $\mathrm{Inx}$, respectively. GL - degree of freedom; ${ }^{\text {n }}$ not significant; ${ }^{* *}$ significant at the level of $1 \%$ probability $(\mathrm{p}<0.01) ;{ }^{*}$ significant at the level of $5 \%$ probability $(0.01 \leq$ $\mathrm{p}<0.05)$ by the $\mathrm{F}$ test $\mathrm{CV}=$ coefficient of variance; $\mathrm{Q}=$ Quadratic; $\mathrm{L}=$ Linear regression.

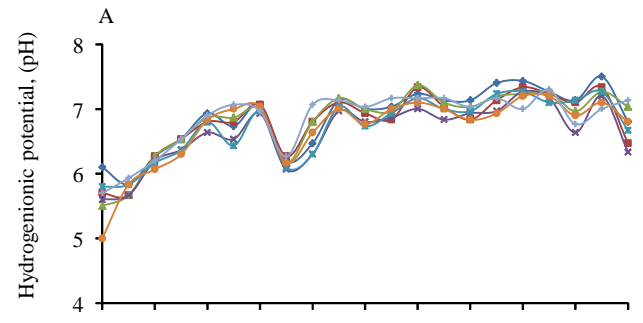

B
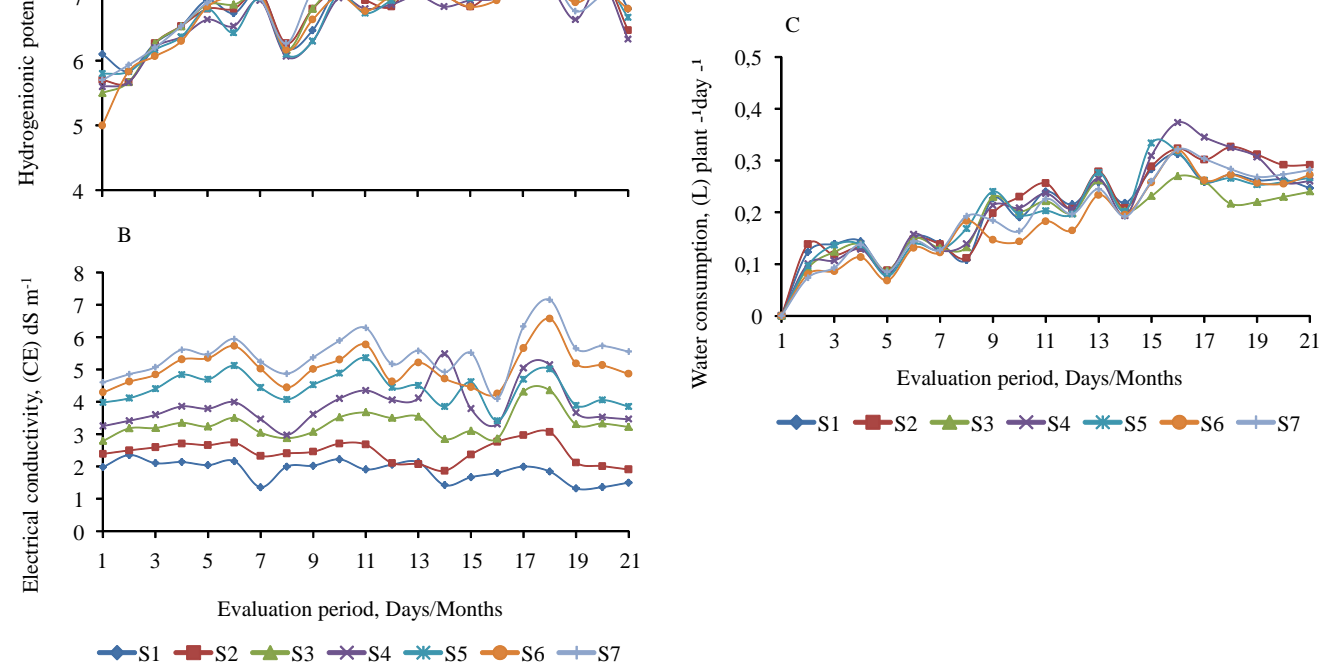

Fig 1. Variation of hydrogen potential $(A)$, Electrical conductivity $(B)$ and water consumption (C) of the three lettuce cultivars during the experimental period of nutrient solutions $\mathrm{S}_{1}=100 \%$ of Furlani solution (EC $1.9 \mathrm{dS} \mathrm{m}^{-1}$ ) and $\mathrm{S}_{2} ; \mathrm{S}_{3} ; \mathrm{S}_{4} ; \mathrm{S}_{5} ; \mathrm{S}_{6}$ and $\mathrm{S}_{7}$ added with sodium chloride (NaCl) in order to have the following electrical conductivities: $2.4 ; 2.9 ; 3.4 ; 3.9 ; 4.4$ and $4.9 \mathrm{dS} \mathrm{m}^{-1}$, respectively.

\begin{tabular}{lc} 
Table 2. Physical-chemical characterization of waters used in hydroponic irrigation. \\
\hline Determinations & Rain water \\
\hline $\mathrm{pH}$ & 8.09 \\
Electric conductivity $\left(\mathrm{dS} \mathrm{m}^{-1}\right)$ & 0.156 \\
Calcium $\left(\mathrm{mmol}_{\mathrm{c}} / \mathrm{L}\right)$ & 1.20 \\
Magnesium $\left(\mathrm{mmol}_{\mathrm{c}} / \mathrm{L}\right)$ & 0.15 \\
Sodium $\left(\mathrm{mmol}_{\mathrm{c}} / \mathrm{L}\right)$ & 0.12 \\
Potassium $\left(\mathrm{mmol}_{\mathrm{c}} / \mathrm{L}\right)$ & 0.07 \\
Chlorides $\left(\mathrm{mmol}_{\mathrm{c}} / \mathrm{L}\right)$ & 0.50 \\
Carbonates $\left(\mathrm{mmol}_{\mathrm{c}} / \mathrm{L}\right)$ & 0.20 \\
Bicarbonate $\left(\mathrm{mmol}_{\mathrm{c}} / \mathrm{L}\right)$ & 0.90 \\
Sulfates $\left(\mathrm{mg} \mathrm{L}^{-1}\right)$ & $\mathrm{bbsent}$ \\
Sodium adsorption ratio $(\mathrm{SAR})$ & 0.15 \\
Class of water for irrigation & $C_{1}$ \\
\hline
\end{tabular}
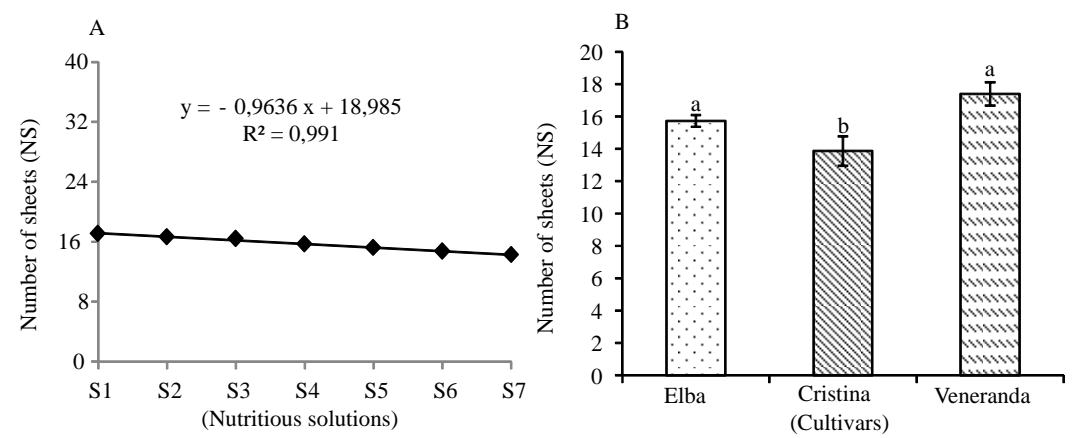

Fig 2. Number of leaves per Plant (NLP) of lettuce as a function of the isolated effect of nutrient solutions $S_{1} ; S_{2} ; S_{3} ; S_{4} ; S_{5} ; S_{6}$ and $S_{7}(A)$ and the lettuce cultivars Elba, Cristina and Veneranda (B). $\mathrm{S}_{1}=100 \%$ of Furlani solution (EC $1.9 \mathrm{dS} \mathrm{m}^{-1}$ ) and $\mathrm{S}_{2} ; \mathrm{S}_{3} ; \mathrm{S}_{4} ; \mathrm{S}_{5} ; \mathrm{S}_{6}$ and $\mathrm{S}_{7}$ added with sodium chloride $(\mathrm{NaCl})$ in order to have the following electrical conductivities: $2.4 ; 2.9 ; 3.4 ; 3.9 ; 4.4$ and $4.9 \mathrm{dS} \mathrm{m}^{-1}$, respectively. 
Table 3. Chemical composition of mineral nutritive solutions.

\begin{tabular}{ll}
\hline & Solution $\mathrm{g} 1000 \mathrm{~L}^{-1}$ of water \\
\hline Mineral salts & Furlani \\
\hline NO3 - Nitrate & 200.44 \\
NH4 - Ammonium & 16.51 \\
P - Phosphor & 32.70 \\
K - Potassium & 310.27 \\
Ca - Calcium & 168 \\
Mg - Magnesium & 24.65 \\
S - Sulfur & 32.5 \\
Mn - Manganese & 0.63 \\
Zn - Zinc & 0.19 \\
Cu - Copper & 0.06 \\
Bo - Boron & 0.35 \\
Mo - Molybdenum & 0.11 \\
Fe - Iron & 2.23 \\
\hline
\end{tabular}

A

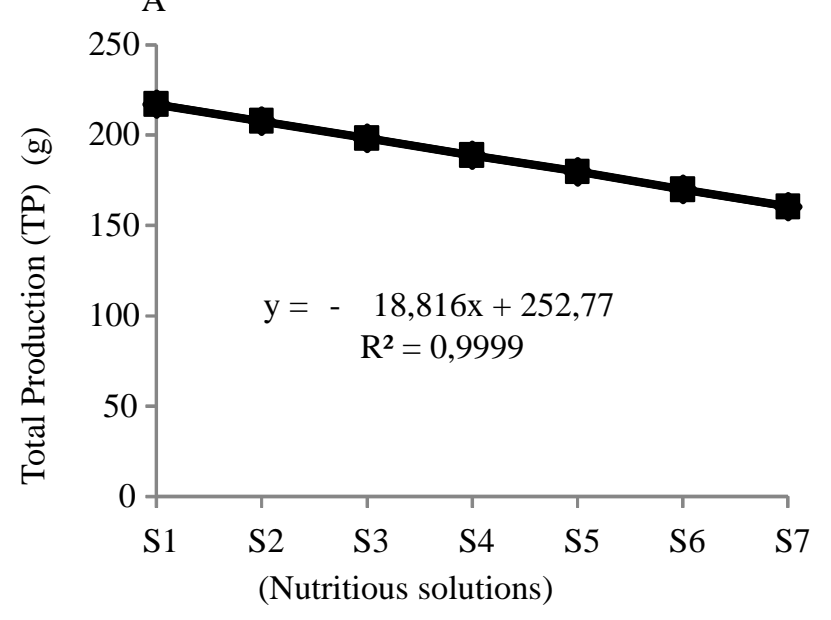

B

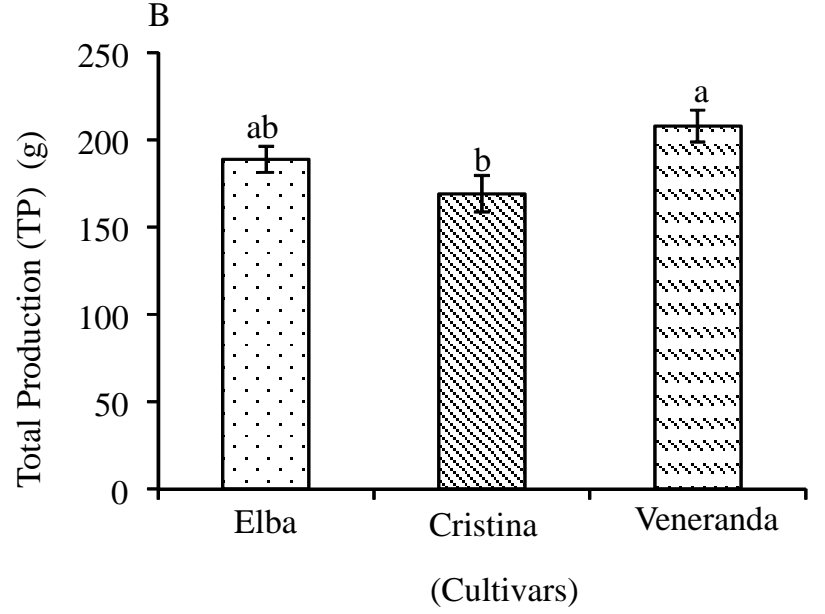

Fig 3. Total lettuce production (TP) as a function of the isolated effect of nutrient solutions solutions $S_{1} ; S_{2} ; S_{3} ; S_{4} ; S_{5} ; S_{6}$ and $S_{7}(A)$ and the lettuce cultivars Elba, Cristina and Veneranda (B). $\mathrm{S}_{1}=100 \%$ of Furlani solution (EC $1.9 \mathrm{dS}^{-1}$ ) and $\mathrm{S}_{2} ; \mathrm{S}_{3} ; \mathrm{S}_{4} ; \mathrm{S}_{5} ; \mathrm{S}_{6}$ and $\mathrm{S}_{7}$ added with sodium chloride $(\mathrm{NaCl})$ in order to have the following electrical conductivities: $2.4 ; 2.9 ; 3.4 ; 3.9 ; 4.4$ and 4.9 dS $\mathrm{m}^{-1}$, respectively.
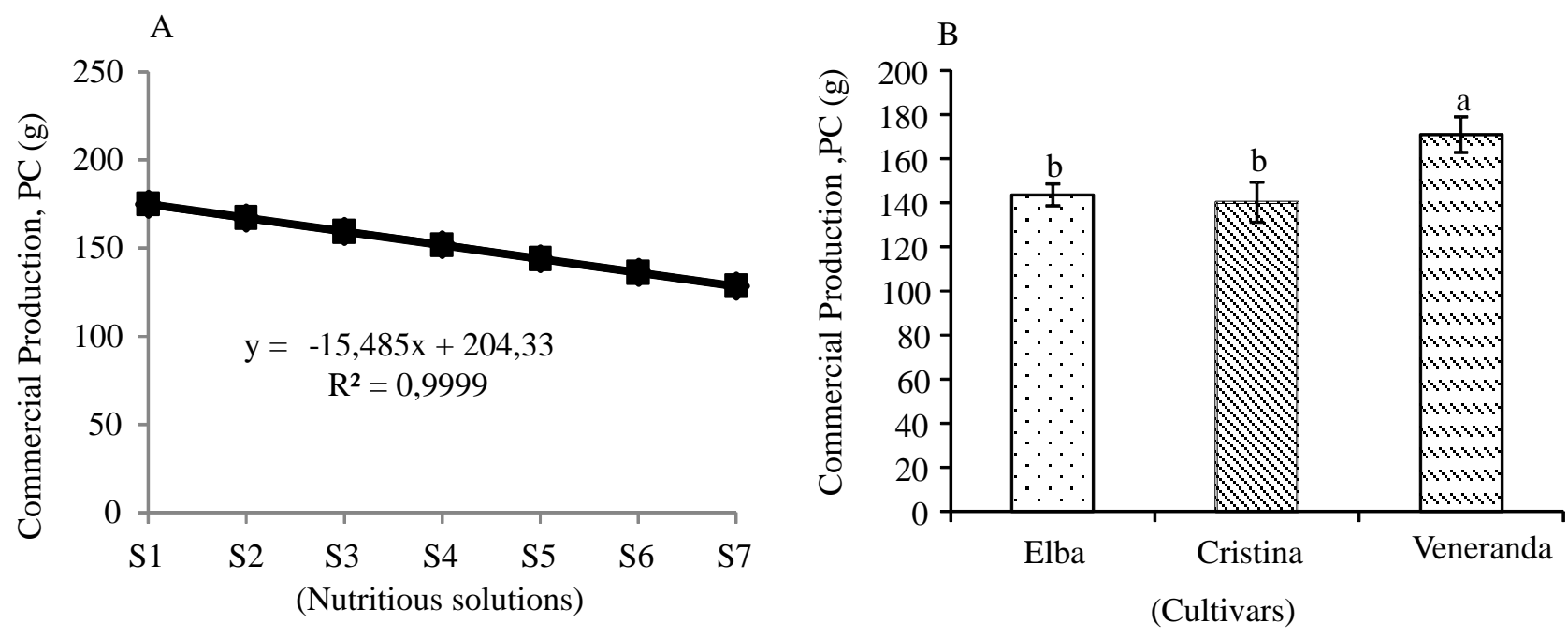

Fig 4. Commercial production (CP) of lettuce as a function of the isolated effect of nutrient solutions $\mathrm{S}_{1} ; \mathrm{S}_{2} ; \mathrm{S}_{3} ; \mathrm{S}_{4} ; \mathrm{S}_{5} ; \mathrm{S}_{6}$ and $\mathrm{S}_{7}(\mathrm{~A})$ and the lettuce cultivars Elba, Cristina and Veneranda (B). $\mathrm{S}_{1}=100 \%$ of Furlani solution (EC $1.9 \mathrm{dS} \mathrm{m}^{-1}$ ) and $\mathrm{S}_{2} ; \mathrm{S}_{3} ; \mathrm{S}_{4} ; \mathrm{S}_{5} ; \mathrm{S}_{6}$ and $\mathrm{S}_{7}$ added with sodium chloride $(\mathrm{NaCl})$ in order to have the following electrical conductivities: $2.4 ; 2.9 ; 3.4 ; 3.9 ; 4.4$ and 4.9 dS $\mathrm{m}^{-1}$, respectively. 
A

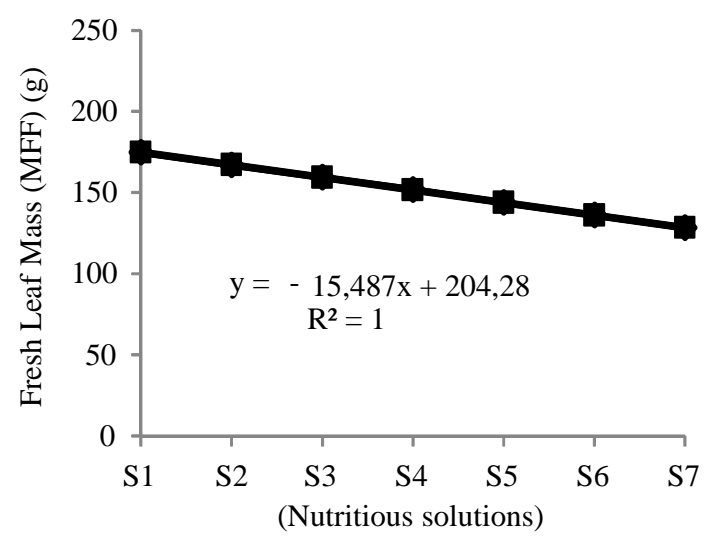

B

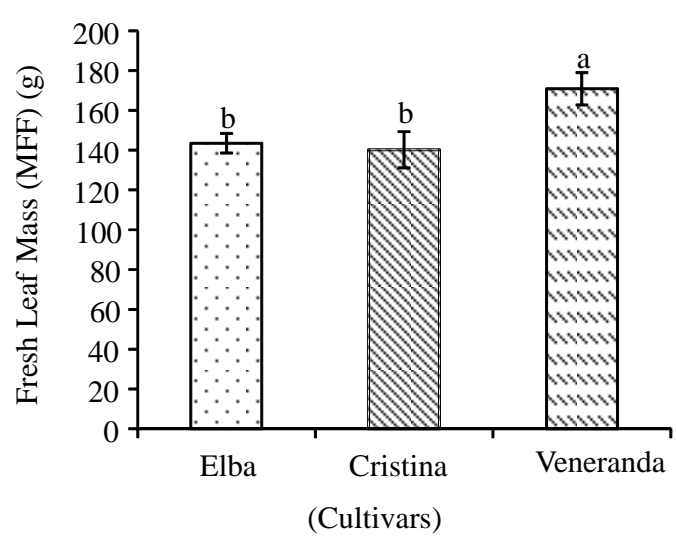

Fig 5. Fresh Leaf Mass (FLM) (g) of lettuce as a function of the isolated effect of nutritional solutions $S_{1} ; S_{2} ; S_{3} ; S_{4} ; S_{5} ; S_{6}$ and $S_{7}$ (A) and the lettuce cultivars Elba. Cristina and Veneranda (B). $S_{1}=100 \%$ of Furlani solution (EC $1.9 \mathrm{dS} \mathrm{m}^{-1}$ ) and $\mathrm{S}_{2} ; \mathrm{S}_{3} ; \mathrm{S}_{4} ; \mathrm{S}_{5} ; \mathrm{S}_{6}$ and $\mathrm{S}_{7}$ added with sodium chloride $(\mathrm{NaCl})$ in order to have the following electrical conductivities: $2.4 ; 2.9 ; 3.4 ; 3.9 ; 4.4$ and $4.9 \mathrm{dS}^{-1}$, respectively.
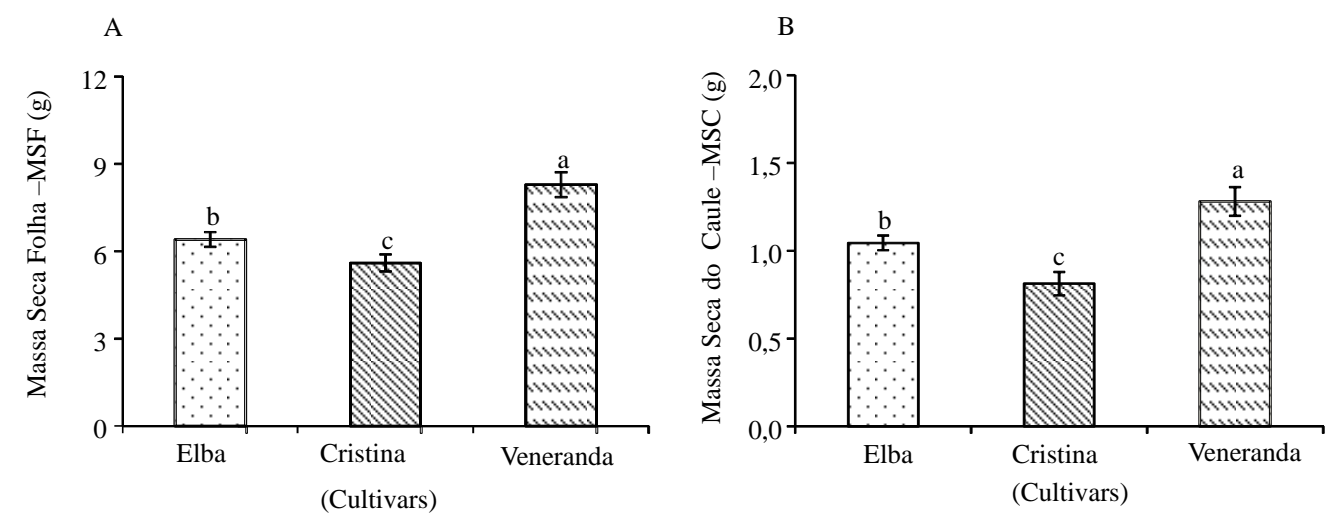

Fig 6. Dry leaf mass (A) and Dry stem mass (B) (g) depending on the effect of the lettuce cultivars Elba, Cristina and Veneranda.

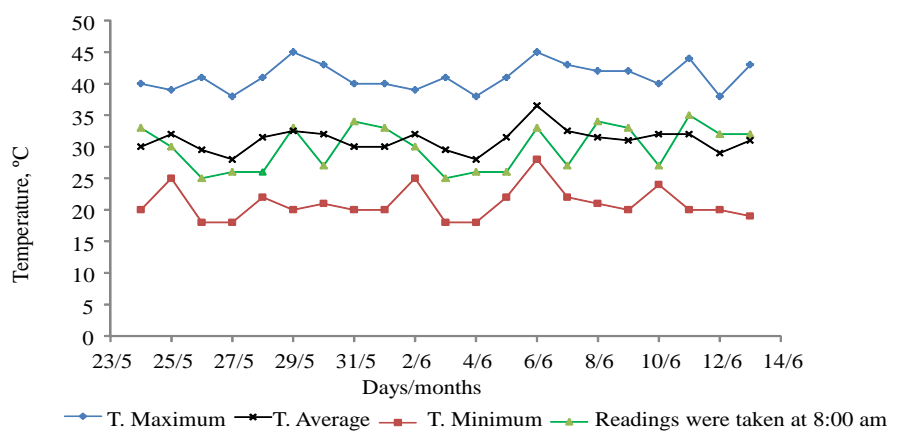

Fig 7. Maximum, minimum and average temperature data. Temperatures recorded at 8:00 am during the conduct of the experiment.

of Paraíba (UEPB), located in the rural area of the city of Lagoa Seca-PB, with the following geographical coordinates: $7^{\circ} 10^{\prime} 15^{\prime \prime} \mathrm{S}, 35^{\circ} 51^{\prime} 14^{\prime \prime} \mathrm{W}$, according to the Köppen-Geige climate classification (Brazil, 1971). The municipality's climate is characterized as humid tropical, with an average annual temperature of around $22^{\circ} \mathrm{C}$, the minimum being 18 ${ }^{\circ} \mathrm{C}$ and the maximum $33^{\circ} \mathrm{C}$.

\section{Plant materials}

We used a $11 \times 23$ meters greenhouse with a height of 2.2. An agricultural screen with $50 \%$ brightness was applied on the sides of the greenhouse and translucent polycarbonate tiles were used on the roof. During the experiment leading, the temperature values (maximum, minimum, average and temperatures at 8:00 am) were recorded daily (Fig. 7).

The hydroponic system was the Nutrient film technique (NFT), using gutters of $100 \mathrm{~mm}$ in diameter and $3 \mathrm{~m}$ in length. The structure consisted of 42 rails, distributed over 21 benches. The gutters were installed with a $3 \%$ slope. The reservoirs containing the solution had a capacity of $20 \mathrm{~L}$. However, to avoid wasting solution by overflowing the bucket we used only $85 \%$ of its capacity. In order to keep the nutrient solution within the temperature limits recommended for hydroponic cultivation, the buckets were covered with sheets of Ethylene Vinyl Acetate with a thickness of $5 \mathrm{~mm}$. 


\section{Conduction and installation of experiment}

The experiment was designed in randomized blocks with $7 x$ 3 subdivided plots, each plot consisted of seven nutrient solutions: $\mathrm{S}_{1}=$ Furlani (EC $1.9 \mathrm{dS} \mathrm{m}^{-1}$ ) and six solutions added Sodium chloride $(\mathrm{NaCl})$ in order to have the following electrical conductivities: $\left(\mathrm{S}_{2}-2.4 ; \mathrm{S}_{3}-2.9 ; \mathrm{S}_{4}-3.4 ; \mathrm{S}_{5}-3.9 ; \mathrm{S}_{6}-4.4\right.$

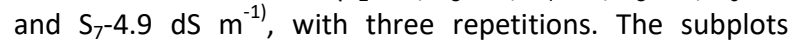
corresponded to the culture of curly lettuce composed of three cultivars (Elba, Cristina and Veneranda), presenting 10 plants by subplot.

The water used in the experiment was extracted from rainwater and stored in a cistern for all solutions and sent to the Irrigation and Salinity Laboratory of the Agricultural Engineering Academic Unit (ISL/UAEA/UFCG) for physicalchemical analysis (Table 2).

All nutrient solutions were prepared according to the methodology proposed by Furlani (1995) for a 200 liters solution volume (Table 3 ). The electrical conductivity of solutions $\mathrm{S}_{2}$ to $\mathrm{S}_{7}$, were obtained with the addition of $\mathrm{NaCl}$, thus forming seven stock solutions.

The formulation of the solutions was carried out using the SOLVER tool. For this, an electronic spreadsheet was created in Microsoft Office Excel containing the chemical composition of the water; (calcium nitrate, potassium nitrate, potassium phosphate, monoammonium phosphate, potassium chloride, magnesium sulphate and in the form of sulphate, the micronutrients copper, zinc, manganese and iron).

Sowing of the three cultivars of curly lettuce were carried out in trays and in phenolic foam with (three) $3 \mathrm{~cm}$ in diameter and (two) $2 \mathrm{~cm}$ in height previously rinsed with running water to eliminate possible remaining acidic compounds from their manufacture. During the first six days, the foams were moistened only with water from the city of Campina Grande-Paraíba. On the 7th, 13th and 19th days, the solution $\mathrm{S}_{1}$ was added, so that it presented, respectively, $33.33 ; 66.66$ and $100 \%$ of the nutritional concentration suggested by Furlani (1995). The seedlings were kept in the nursery for 24 days after germination.

\section{Monitoring and calibration of nutrient solutions}

During the conduct of the experiment, the monitoring took place daily, in an interval of 24 hours, taking readings of the solutions and calibrating the hydrogen potential $(\mathrm{pH})$, the electrical conductivity (EC) using a portable conductivity meter of hydrogen potential $(\mathrm{pH})$, and solids total dissolved (STD)/Temperature model HI 9811-5.

After calibration, the $\mathrm{pH}$ of the solutions was adjusted keeping it close to neutral, using a solution of sodium hydroxide $(\mathrm{NaOH})$ or $(\mathrm{HCL}) \mathrm{H}_{2} \mathrm{SO}_{4}\left(1 \mathrm{~mol} \mathrm{~L}^{-1}\right)$. The $\mathrm{pH}$ variation was made considering the average molar concentration of the $\mathrm{H}+$ ions using the expression $\mathrm{pH}=-\log$ $\left[\mathrm{H}^{+}\right]$.

The management of nutrients solutions was performed daily by replacing the consumed water, using rain water in order to reach the initial volume (17L). After replacement, a new solution was made from the stock solutions, when results with greater or lesser variation than $20 \%$ verified in the initial electrical conductivity; thus, returning the EC to its original value. During the handling of the solution, the variation in electrical conductivity (EC) and hydrogen potential $(\mathrm{pH})$ was also evaluated, keeping it close to neutrality, using a solution of $\mathrm{NaOH}$ or $\mathrm{HCL}\left(1 \mathrm{~mol} \mathrm{~L}^{-1}\right)$.

\section{Estimated water consumption}

The quantification of evapotranspirated volume by the cultivars (VETc) was performed daily, depending on the solutions, completing the volume of the reservoir to the level of 17 liters, using a cylinder graduated in milliliters according to Equation 1. VETc was considered as a quantitative variable to establish a regression analysis polynomial.

$\mathrm{VETC}=\frac{V i}{n \cdot \Delta t}$

VETc - evapotranspiration volume, in $\mathrm{L} \mathrm{plant}^{-1}$ day $^{-1}$;

$\mathrm{Vi}$ - volume of solution consumed in the $24 \mathrm{~h}$ time interval;

$\Delta T$ - time interval between readings, days;

$\mathrm{n}$ - number of plants in the profile in the time interval, $\Delta T$.

\section{Evaluated characteristics}

Depending on the treatments, lettuce was evaluated 20 days after transplanting to the hydroponic profile for the following parameters:

$\mathrm{pH}, \mathrm{EC}$ and water consumption depending on the evaluation period.

Number of leaves per plant (NLP): consisted of counting the number of leaves from commercial production starting from the basal leaves until the last open leaf;

Stem diameter (SD): obtained through direct measurement $(\mathrm{mm})$ with the aid of a digital caliper.

Total production (TP): consisted of the production of fresh mass of the aerial part (stem and leaves) being determined with the aid of a semi-analytical scale;

Commercial production (CP): it consisted of the production of fresh mass of the aerial part (stem and leaves) disregarding the yellowed leaves, dried and / or attacked by pests and diseases, being determined with the aid of a semianalytical scale

Dry mass of leaves (DML) and stem (DMS): the plants were placed in paper bags, remaining on a bench for 7 days at room temperature (average $28^{\circ} \mathrm{C}$ ). After that period, they were placed for drying in forced circulation air at $70 \stackrel{\circ}{ }{ }^{\circ}$, until reaching constant weight, expressed in grams.

\section{Statistical analysis}

The results obtained were submitted to the homogeneity test (Cochran and Bartlett), and to the normality test (Shapiro-Wilk). The growth and production parameters were subjected to analysis of variance by the $F$ test at 1 and $5 \%$ probability. When there was a significant effect in the analysis of variance, the averages obtained in the subplots (cultivars) were compared using the Tukey test up to 5\% probability and between the plots (solutions) regression will be used using the SISVAR statistical software (Ferreira, 2014).

\section{Conclusions}

Nutritional solutions $\left(\mathrm{S}_{1}=1.9\right.$ and $\left.\mathrm{S}_{2}=2.4 \mathrm{dS} \mathrm{m}^{-1}\right)$ promoted the best results for all variables studied. The lowest results for leaf numbers (LN), total production (TP), commercial production (CP) and fresh leaf mass (FLM) were obtained with the nutrient solution $\left(\mathrm{S}_{7}=4.9 \mathrm{dS} \mathrm{m}^{-1}\right)$. The highest number of leaves (LN) was found in the cultivars Elba and 
Veneranda when the solutions were used $\left(\mathrm{S}_{1}=1.9\right.$ and $\mathrm{S}_{2}=$ $2.4 \mathrm{dS} \mathrm{m}^{-1}$ ). The highest production for the variables; total production (TP) and commercial production (CP) were found in the cultivar Veneranda irrigated with nutrient solutions $\left(\mathrm{S}_{1}\right.$ $=1.9$ and $S_{2}=2.4 \mathrm{dS} \mathrm{m}^{-1}$ ). The highest value for (DLM) and Dry stem mass (DSM) was found in the cultivar Veneranda.

\section{Acknowledgments}

Thanks to the Coordination for the Improvement of Higher Education Personnel - CAPES for the granting of a financial support to carry out the research.

\section{References}

Alves MS, Soares TM, Silva LT, Fernandes JP, Oliveira MLA, Paz VPS, (2011) Estratégias de uso de água salobra na produção de alface em hidroponia NFT. Rev Bras de Eng Agríc e Ambient. 15: 491-498.

Ayers RS, Westcot DW (1999) A qualidade da água na agricultura. Estudos Organização das Nações Unidas para a Alimentação e a Agricultura (FAO) Irrigação e Drenagem. ed. 153p. Campina Grande UFPB.

Braccini, MCL, Braccini ALE, Martinez HEP, (1999) Critérios para renovação ou manutenção de solução nutritiva em cultivo hidropônico. Rev Ciênc Agrar. 20: 48-57.

Brasil (1971) Ministério da Agricultura. Equipe de Pedologia e Fertilidade do Solo. Levantamento exploratório. Reconhecimento de solos do estado da Paraíba. Rio de Janeiro, SUDENE, 670p. (Boletim Técnico, 15).

Castellane PD, Araújo JAC, (1995) Cultivo sem solohidroponia. Jaboticabal: Funep. 43p.

Cazuza Neto A, Soares TM, Bione, MA, Freitas FTO, Melo DM, Silva Filho JA, (2014) Qualidade do molho de coentro produzido em água salobra em sistema hidropônico NFT. In: II Brazilian Symposium on Salinity \& II Brazilian Meeting on Irrigation Engineering, Anais. Fortaleza, 3678-3684p.

Dias NS, Jales AGO, Sousa Neto ON, Gonzaga MIS, Queiroz ISR, Porto MAF, (2011) Uso de rejeito da dessalinização na solução nutritiva da alface, cultivada em fibra de coco. Rev Ceres. 58: 632-637.

Ferreira DF (2014) Sisvar: A Guide for its Bootstrap procedures in multiple comparisons. Ciênc Agrotec. 38: 109-112.

Filgueira, FAR (2008) Novo manual de olericultura: agrotecnologia moderna na produção e comercialização de hortaliças. 3. ed. 421p.Viçosa UFV.

Furlani PR (1995) Cultivo de alface pela técnica de hidroponia - NFT. Campinas, IAC, 18p. (IAC Documentos 55).

Gomes LS, Martins CAS, Nogueira NO, Lopes FS, Xavier TMT, Cardoso LCM, (2011) Efeito de diferentes valores de pH da solução nutritiva no desenvolvimento de variedades de melão. Rev Bras de Ciênc Agrar. 6: 73-78.

Gondim ARO, Flores MEP, Martinez HEP, Fontes PCR, Pereira PRG, (2010) Condutividade elétrica na produção e nutrição de alface em sistema de cultivo hidropônico NFT. Bioscience J. 26: 894-904.

Helbel Junior C, Rezende FRJA, Santos HS, Dallacort R, (2007) Produção hidropônica da cultura da alface com soluções nutritivas e vazões distintas. Acta Scientiarum Agronomy. 29: 391-395.

Henz GP, Suinaga F (2009) Tipos de alface cultivados no Brasil. Brasília, Embrapa Hortaliças. 7p. (Comunicado Técnico, 75).
Lira RM, Silva EFF, Silva GF, Santos AN, Rolim MM, (2015) Production, water consumption and nutrient content of Chinese cabbage grown hydroponically in brackish water. Rev Ciênc Agron. 46: 497-505.

Magalhães AG, Menezes D, Resende LV, Bezerra Neto E, (2010) Desempenho de cultivares de alface em cultivo hidropônico sob dois níveis de condutividade elétrica. Hort Bras. 28: 316-320.

Martinez HEP, (2002) O uso do cultivo hidropônico de plantas em pesquisa. Viçosa: UFV. Caderno Didático. 61p.

Monteiro Filho AF, Azevedo CAV de, Azevedo MRQA, Fernandes JD, Silva CR, Fernandes PD, (2018) Monitoring, calibration and maintenance of optimized nutrient solutions in curly lettuce (Lactuca sativa, L.) hydroponic. Aust J Crop Sci. 12(04): 572-582.

Monteiro Filho AF, Azevedo MRQA, Azevedo CAV, Fernandes JD, Silva CR, Silva YS (2017) Growth of hydroponic lettuce with optimized mineral and organomineral nutrient solutions. Rev Bras Eng Agric Ambiet. 21: 191-196.

Monteiro Filho AF, (2015) Análise técnica e econômica da alface crespa cultivada hidroponicamente com soluções minerais e organominerais otimizadas. Tese de Doutorado. Universidade Federal de Campina Grande. 165p.

Monteiro Filho AF, Pereira GL, Azevedo MRQA, Fernandes JD, Azevedo CAV (2014) Cultivo hidropônico de cultivares de alface em soluções nutritivas organominerais otimizadas com a ferramenta Solver. Rev Bras de Eng Agríc e Ambient. 18: 417-424.

Oliveira LLP, Farias WC, Linhares PSF, Melo MRS, Cavalcante JJ, Dombronski JLD, (2014) Análise de diferentes dosagens de solução nutritiva no cultivo de mudas de alface americana (Lactuca sativa L.). Rev Agrop Científ no Semiárido. 10: 14-17.

Oliveira FA, Carrilho, MJSO, Medeiros JF, Maracajá PB, Oliveira MKT, (2011) Desempenho de cultivares de alface submetidas a diferentes níveis de salinidade da água de irrigação. Rev Bras de Eng Agríc e Ambient. 15: 771-777.

Paulus D, Dourado Neto D, Frizzone JA, Soares TM, (2010) Produção e indicadores fisiológicos de alface sob hidroponia com água salina. Rev Hort Bras. 28: 29-35.

Santos RSS, Dias NS, Duarte SN, Lima CJGS, (2012) Uso de águas salobras na produção de rúcula cultivada em substrato de fibra de coco. Rev Caat. 25: 113-118.

Sanchez SV (2007) Avaliação de cultivares de alface crespa produzidas em hidroponia tipo NFT em dois ambientes protegidos em Ribeirão Preto (SP). 63p. Dissertação (Mestrado em Agronomia) Faculd de Ciênc Agrar e Veterin (UNESP), Jaboticabal, São Paulo.

Silva MG, Soares TM, Oliveira IS, Santos JCS, Pinho JS, Freitas FTO, (2015) Produção de coentro em hidroponia-NFT com o uso de águas salobras para reposição do consumo evapotranspirado. Fortaleza, CE. Rev Bras de Agricult Irrig. 9: 246 - 258.

Silva AO, Silva DJR, Soares TM, Silva EFF, Santos AN, Rolim MM, (2011) Produção de rúcula em sistema hidropônico NFT utilizando água salina do Semiárido-PE e rejeito de dessalinizador. Rev Bras de Ciênc Agrar. 6: 147-155.

Silva ET, Schwonka F, (2001) Viabilidade econômica para a produção de alface no sistema hidropônico em Colombo, Curitiba, PR. Scient Agrar. 2: 111-116.

Souza Neta ML, Oliveira FA, Silva RT, Souza AAT, Oliveira MKT, Medeiros JF, (2013) Efeitos da salinidade sobre o desenvolvimento de rúcula cultivada em diferentes substratos hidropônicos. Rev Agro@mb. 7: 154-161. 
Soares HR, Silva EFF, Silva GF, Pedrosa EMR, Rolim MM, Santos AN, (2015) Lettuce growth and water consumption in NFT hydroponic system using brackish water. Rev Bras de Eng Agríc e Ambient. 19: 636-642.

Soares TM, Duarte SN, Silva EFFE, Jorge CA, (2010) Combinação de águas doce e salobra para produção de alface hidropônica. Rev Bras de Eng Agríc e Ambient. 14: 705-714.
Word Health Orgazination -WHO, (2013) Water Security \& the Global Water. Agenda AUN -Water Analytical Brief. Canada. (Report of a WHO meeting of experts).

Xavier JF, Azevedo CAV, Azevedo MRQA, Dantas JF, Monteiro Filho AF, Lima, VLA (2019) Application of wastewater for production of lettuce (Lactuca sativa) in hydroponic system. Aust J Crop Sci. 13 (10): 1586-1593. 